\section{GREEN CORPORATE SOCIAL RESPONSIBILITY ON THE CAPITAL MARKET - CAN ECO-RESPONSIBILITY BE PROFITABLE?}

\author{
Anna Laskowska \\ Nicolaus Copernicus University \\ Faculty of Economic Sciences and Management, Torun, Poland \\ e-mail: anna.las@doktorant.umk.pl
}

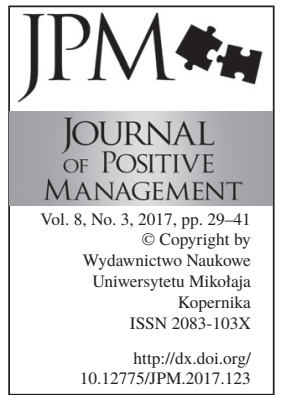

1. 8, No. 3, 2017, pp. 29-41 Kopernika

http://dx.doi.org/ 10.12775/JPM.2017.123

\begin{abstract}
Purpose: The hereby thesis aims at an analysis of the effectiveness of green CSR on the financial market and, more precisely, eco-ethical SRI investments in the form of investment funds and stock market indices. The studies presented will be correlated to research hypotheses regarding SRI portfolios.

Methodology: The paper was written after an in-depth analysis of the literature of the subject, thereby applying the literature review research method, focused mainly on studies measuring the efficiency eco-ethical investing on the example: investment funds and stock market indices.

Findings: The results show that green CSR can lead to gains for the investors, outperforming the benchmarks. The conclusion is made with a high degree of distrust but if "gains" are understood as the totality of benefits for the investor, the thesis becomes more certain. CSR and SRI have a number of other advantages, such as reduction of investment risk or improvement of the image and the natural environment. According to scientists, there is usually no difference between the viability of eco-ethical and traditional investments, what confirms the "no effect" hypothesis.

Implications/limitations: The paper presents effectiveness of eco-ethical investments in the light of scientific literature and may constitute a basis for further research. In addition, the author suggested specific directions for future analysis. The paper may have its weak points, referring to comparative analysis of studies by different authors which, due to multifarious guidelines, e.g. sample size, time horizon, are sometimes difficult to be confronted with one another.

Originality: The activity of financial institutions has an undisputed ecological dimension. Therefore, when making investment decisions, it is advised to take environmental factors into consideration. The number of researches referring to the efficiency of SRI investments, mainly those ecologically oriented, is not that large - especially in Poland. Moreover, the aim of the author was to present the most geographically and temporally diverse ranges of analyses possible. Therefore, this article can be valuable for further research.
\end{abstract}

Keywords: corporate social responsibility, socially responsible investing, green investing

Paper type: Literature review 
GREEN CORPORATE SOCIAL RESPONSIBILITY

Anna Laskowska

\section{Introduction}

The role of social-environmental aspects in business has become more and more important in recent times. Terms such as: sustainability, CSR, SRI, ESR or ecology have permanently appeared in the mind-set, language and everyday functioning of financial market entities. The development of socially responsible business conception is reflected on the capital market as the idea of socially responsible investing.

Environmental protection has now become an essential part of CSR in the strategy of listed companies, but is it economic? In their investment decisions, participants of the capital market adjust to ecological criteria and new green financial instruments constantly appear - in other words, "green" evolution of financial market is now taking place. All this is cause for thought, regarding the direction of green CSR development on the financial market and, most of all, to what extent this trend is profitable.

The aim of the hereby thesis is to analyse the effectiveness of green CSR on the financial market, namely eco-ethical SRI investments in the form of investment funds and stock market indices. Another objective is to answer the question whether such investments are capable of reaching higher return rates when compared to model investments. Moreover, the presentation of empirical research aims at providing a more in-depth insight into the subject area of the profitability of eco-investing. The paper was written after a thorough analysis of the literature of the subject, thereby applying the literature review research method.

In the first part of the article the notion of green CSR on the capital market will be discussed. An attempt to define cost-effectiveness of eco-ethical investments in the light of the bibliographic analyses and scientists' opinions will be made in the second part of the paper. The studies presented will be correlated to research hypotheses regarding SRI portfolios, resulting in conclusions as to the profitability of "green" responsibility from the scientific perspective. In addition to that, suggested directions for future research on the subject area mentioned in the title will be indicated.

\section{Methodology}

The main research method applied in the article is literature review, focused mainly on studies measuring the efficiency eco-ethical investing on the example of two financial products: investment funds and stock market indices. Taking into account the non-objectivism of opinions, the subject literature critical review method was not forgotten. The materials used in the paper contained the results of scientific researches from both foreign and domestic academic centres. The source of information adequate for literature review were bibliographic search engines dedicated for academic purposes, such as Google Scholar and ResearchGate. 
It is worth to be stressed that the basic canon of science refers to continuity. This means that subsequent studies should make reference to the previous ones, in order to either expand the current state of knowledge or to refute it. Therefore, while analysing the literature chronologically it can be noted that the research

GREEN CORPORATE SOCIAL RESPONSIBILITY

Anna Laskowska subject has accumulation features and the growth of the phenomenon is uneven temporary cognitive gaps can occur (Czakon, 2011). So it is in the hereby thesis. What is more, selection of the sample from numerous publications can result in a decrease in completeness of the research.

While choosing the analyses, a selection based on the following key words was conducted: effectiveness of socially and ecologically responsible investments, socially and ecologically responsible investing, sustainability and ecological stock market indices, green investment funds, socially responsible investment funds, ethical investment funds. The articles were then verified by applying exclusion criteria and removing repeating reference items. Each research was supposed to refer to disparate capital market entities or to be conducted in a completely different way. The aim of the author was also to present the most geographically and temporally diverse ranges of analyses possible. Contrary to appearances, the number of researches referring to the efficiency of SRI investments, mainly those ecologically oriented, is not that large. After exploring those carefully selected papers, structured by the release date, the author summarized them in tables, therefore applying another research method: comparative analysis. The result of it were conclusions relating to the whole of the data set, relevant in terms of dynamic changes occurring in how scientists recognize the "green" business sector.

The thesis may have its weak points, referring to comparative analysis of studies by different authors which, due to multifarious guidelines: sample size, time horizon, market condition or the diversity of sectors analysed, are sometimes difficult to be confronted with one another.

\section{Green CRS - new practice on the capital market}

The main way to partake in the CSR idea on the capital market is to purchase socially responsible financial instruments. The range of SRI instruments is narrower than in the case of CSR practices. Taking into account environmental aspects as well, the number of choices reduces several times.

It is worth to draw attention to the growing importance of the role of environmental protection on the capital market and green banking should be mentioned at this point. Although banks do not offer all green SRI instruments, they are the key institution one has to take into consideration when carrying out a research on the impact environmental protection has on the capital market. Moreover, in many cases banks are owners or co-owners of financial actors such as brokerage houses, consultative institutions, insurance companies, pension 
GREEN CORPORATE SOCIAL

RESPONSIBILITY

Anna Laskowska

Figure 1. Green instruments of the financial market

Source: elaborated by the author based on: (Dziawgo, 2010; Czerwonka, 2013). and investment funds, which offer environmental products of the capital market (Dziawgo, 2007).

The contemporary financial sector offers numerous ways to raise funds in compliance with ecological guidelines. The instruments closely related by design with the market and products resulting from the merging of the banking and capital sectors can be highlighted in this place. Green instruments referring to certain segments of the financial market are presented in Figure 1.

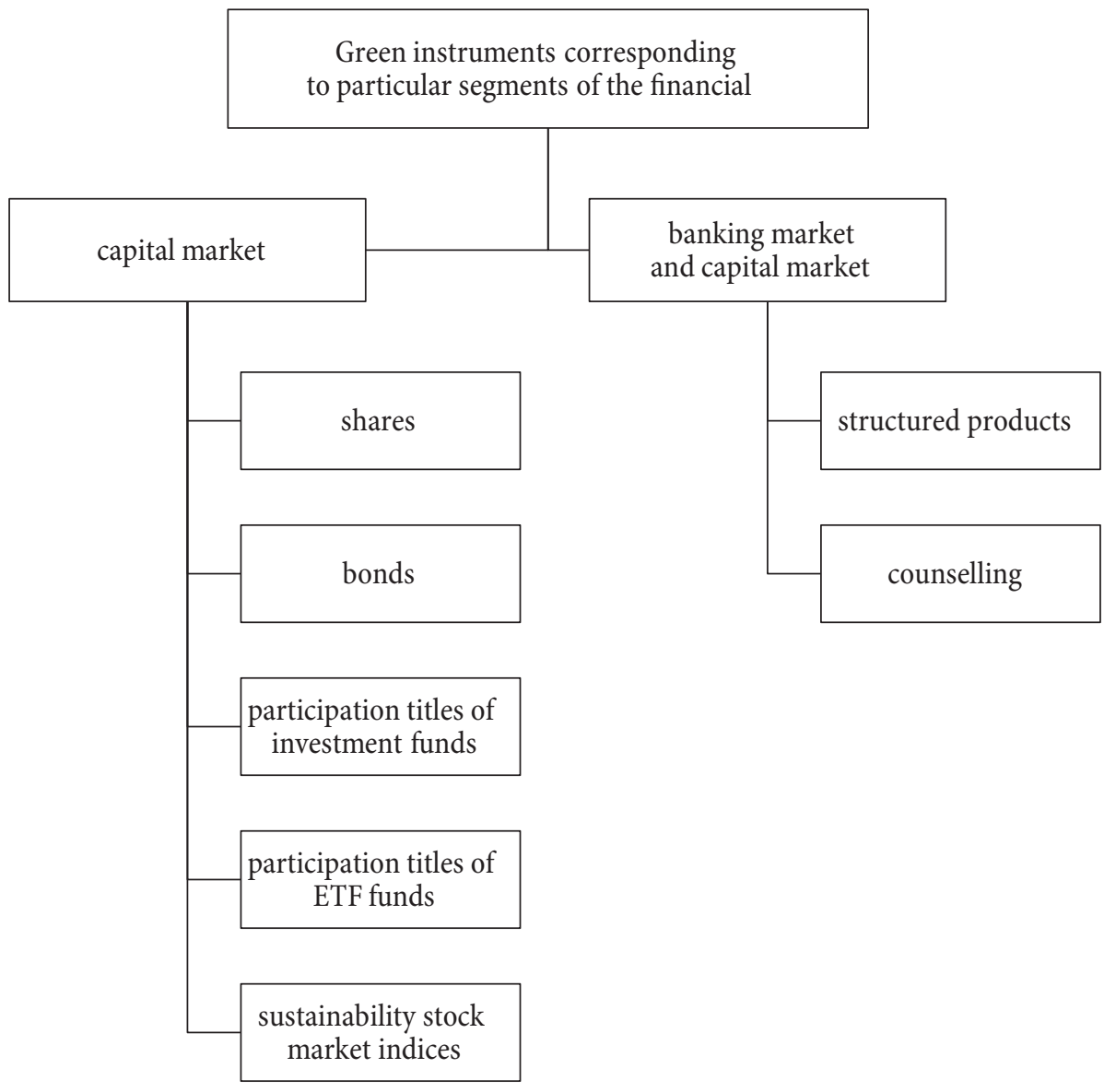

The most popular green SRI instruments are shares. The best known green issuers are companies from the so-called eco-branches that is offering renewable energy sources and ecological food. They are also entities maintaining high environmental standards, for example banks. The process of the environmental assessment of companies is very controversial. For a part of the society, 
introducing the green office policy might be a sufficient factor to name a company "ecological", whereas for others it is definitely not enough to call it a "green" entity (Dziawgo, 2010).

Another SRI tool is a green profiled socially responsible investment fund. It is a specific kind of fund which not only concentrates on making profit but also takes the environmental aspect into consideration. When selecting companies to the portfolio, those who manage the fund apply the principle of environmental protection. As an example, Polish green investment funds are PZU Energia Medycyna Ekologia (Energy Medicine Ecology) and PKO Technologii i Innowacji Globalny (of Technologies and Innovations Global) (Laskowska, 2016).

As a matter of fact, sustainability indices are not instruments through which one can become rich directly, only in the case of creating an ETF fund for the index. However, it should be highlighted that they are an aid when choosing companies meeting environmental requirements and they also monitor the effectiveness of the investments (Laskowska, 2017).

The green financial market also provides opportunities for investing in structured products. Raiffeisen Polbank offers an interesting product for those, who follow the green style of life. It is an investment in the shape of a life insurance policy with an insurance capital fund named EKO Trio. The profit from a structured product depends on the share basket, made up by three companies belonging to the eco-food branch (Analizy.pl).

\section{Effectiveness of eco-ethical investments in the light of scientific literature}

Effectiveness of socially responsible investments has been the subject of numerous scientific publications. Especially since the $20^{\text {th }}$ century, a large number of literature pieces have been documented in reference to SRI investments. Unfortunately, the profitability of green financial instruments exclusively is rarely put under analysis. Their viability is only measured together with other socially responsible products, thus creating a category of eco-ethical investments. The examples of such analyses referring to the relations between the investment results of socially responsible and traditional products are presented in the tables below.

Effectiveness of eco-ethical investment funds will undergo the analysis first. The entire group of SRI funds - social, religion-related, sustainability and ecological - has been the subject of virtually all of the undermentioned studies. Only A. Laskowska verifies the profitability of strictly ecological investment funds, leaving out other socially responsible instruments. In the analyses below, the profitability of funds is compared to the viability of classic investment funds market.

It should be pointed out that studies presented in Table 1 do not give a clear answer regarding the effectiveness of eco-ethical investment funds, compared to 
GREEN CORPORATE

SOCIAL

RESPONSIBILITY

Anna Laskowska
Table 1. An

overview of selected studies relating to the effectiveness of eco-ethical funds'

Source: elaborated by the author based on the literature of the subject listed above.

\begin{tabular}{|c|c|c|c|c|}
\hline $\begin{array}{l}\text { Author/So- } \\
\text { urce }\end{array}$ & $\begin{array}{l}\text { Market un- } \\
\text { der research }\end{array}$ & $\begin{array}{l}\text { Time of } \\
\text { research }\end{array}$ & Conclusions & $\begin{array}{l}\text { Asses- } \\
\text { sment }\end{array}$ \\
\hline $\begin{array}{l}\text { Corner et al., } \\
1992\end{array}$ & UK & 1984-1990 & $\begin{array}{l}\text { SRI funds have a slight trend do } \\
\text { excess the general indicators of the } \\
\text { investment funds market }\end{array}$ & positive \\
\hline $\begin{array}{l}\text { Briston et al., } \\
1995\end{array}$ & UK & 1986-1993 & $\begin{array}{l}\text { SRI funds have a slight trend for } \\
\text { better results, compared to conventio- } \\
\text { nal funds }\end{array}$ & positive \\
\hline Statman, 2000 & USA & 1990-1998 & $\begin{array}{l}\text { in the research, socially responsible } \\
\text { investment funds have achieved sli- } \\
\text { ghtly better results than conventional } \\
\text { funds }\end{array}$ & positive \\
\hline $\begin{array}{l}\text { Geczy et. al., } \\
2003\end{array}$ & USA & 1963-2001 & $\begin{array}{l}\text { substantial statistical differences } \\
\text { between the effectiveness of socially } \\
\text { responsible and traditional funds have } \\
\text { been noticed, to the disadvantage of } \\
\text { SRI field }\end{array}$ & negative \\
\hline $\begin{array}{l}\text { Gray et al., } \\
2005\end{array}$ & $\begin{array}{l}\text { Germany, } \\
\text { Netherlands, } \\
\text { UK, Sweden }\end{array}$ & 1995-2001 & $\begin{array}{l}\text { no substantial differences between the } \\
\text { viability of eco-ethical and standard } \\
\text { portfolios have been noticed }\end{array}$ & neutral \\
\hline $\begin{array}{l}\text { Bauer et al., } \\
2007\end{array}$ & Canada & 1994-2003 & $\begin{array}{l}\text { no statistical differences between the } \\
\text { profits from SRI and traditional funds } \\
\text { have been noticed }\end{array}$ & neutral \\
\hline $\begin{array}{l}\text { Czerwonka and } \\
\text { Wolska, } 2013\end{array}$ & Poland & 2008-2011 & $\begin{array}{l}\text { no clear answer to the question of the } \\
\text { profitability of socially responsible } \\
\text { funds can be given }\end{array}$ & neutral \\
\hline Koop, 2013 & USA & 1985-2012 & $\begin{array}{l}\text { no substantial differences between the } \\
\text { viability of eco-ethical and traditional } \\
\text { funds have been noticed }\end{array}$ & neutral \\
\hline $\begin{array}{l}\text { Cortez and } \\
\text { Leite, } 2014\end{array}$ & Europe & 2000-2008 & $\begin{array}{l}\text { no substantial differences between the } \\
\text { viability of SRI and traditional funds } \\
\text { have been noticed }\end{array}$ & neutral \\
\hline $\begin{array}{l}\text { Nofsinger and } \\
\text { Varma, } 2014\end{array}$ & USA & 2000-2011 & $\begin{array}{l}\text { in a time of crisis, SRI funds feature } \\
\text { higher viability than traditional funds, } \\
\text { whereas when there is no crisis, } \\
\text { conventional funds are more profitable }\end{array}$ & $\begin{array}{l}\text { positive/ } \\
\text { negative }\end{array}$ \\
\hline $\begin{array}{l}\text { Laskowska, } \\
2016\end{array}$ & Poland & 2012-2015 & $\begin{array}{l}\text { green investments included in the } \\
\text { building of investment funds have no } \\
\text { influence on substantial differences } \\
\text { between return rates of those market } \\
\text { participants and their standard coun- } \\
\text { terparts }\end{array}$ & neutral \\
\hline
\end{tabular}


traditional funds. As it can be seen, neutral assessment saying that there are no substantial differences in the profitability between SRI and traditional funds is predominant. In other words, the literature of the subjects proved that eco-ethical investment funds act similarly to other funds. Therefore it can be stated that this trend is worth becoming a part of, as one can contribute to the improvement of natural environment without the risk of a loss. This conclusion, however, is being made with a high degree of uncertainty, due to the selected range of articles and studies conducted in the publications.

It is also worth to get the idea of how scientists assess the effectiveness of sustainability indices. With reference to the Polish market, despite its short, 8-year period of operation, RESPECT Index is the main subject of a number of studies. Due to the criteria adopted, i.e. the diversity of researches, only two researches on RESPECT Index were selected to Table 2. In almost all compilations presented in the table, the authors calculated the results of SRI index and compared them to the conventional pattern. The analysis of $\mathrm{H}$. Sikacz, however, confronts the viability of several socially responsible indices between themselves, without compiling them with the results of traditional stock market indices.

It should also be highlighted there is no test which would analyse green stock market indices exclusively. The range of green stock indices is huge, with the following potential research subjects as examples: Cleantech Index, KLS Global Climate 100 Index, Mac Global Solar Energy Index, MVIS Global Solar Energy Index, Nasdaq Clean Edge Green Energy Index, S\&P Global Clean Energy Index, The FTSE Green Revenues Index Series, and The WilderHill New Energy Global Innovation Index.

The description of selected scientific publications referring to the viability of eco-ethical indices is presented in Table 2.

\begin{tabular}{|c|c|c|c|c|c|}
\hline $\begin{array}{l}\text { Author/ } \\
\text { Source }\end{array}$ & Research & $\begin{array}{l}\text { Market } \\
\text { under } \\
\text { research }\end{array}$ & $\begin{array}{l}\text { Time of } \\
\text { research }\end{array}$ & Conclusions & $\begin{array}{l}\text { Asses- } \\
\text { sment }\end{array}$ \\
\hline $\begin{array}{l}\text { Statman, } \\
2000\end{array}$ & $\begin{array}{l}\text { Domini Social } \\
\text { Index compared } \\
\text { to traditional S\&P } \\
500 \text { index }\end{array}$ & USA & 1990-1998 & $\begin{array}{l}\text { sustainability stock market } \\
\text { index DSI achieved better } \\
\text { investment results than tra- } \\
\text { ditional S\&P } 500 \text { index }\end{array}$ & positive \\
\hline $\begin{array}{l}\text { Christofi et } \\
\text { al., } 2012\end{array}$ & $\begin{array}{l}\text { Dow Jones Su- } \\
\text { stainability Index } \\
\text { World compared to } \\
\text { traditional MSCI } \\
\text { World index }\end{array}$ & $\begin{array}{l}\text { global } \\
\text { reach }\end{array}$ & 1999-2009 & $\begin{array}{l}\text { no statistical differences } \\
\text { between indices have been } \\
\text { noticed }\end{array}$ & neutral \\
\hline
\end{tabular}

SOCIAL RESPONSIBILITY

Anna Laskowska

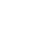


GREEN CORPORATE SOCIAL RESPONSIBILITY

Anna Laskowska

\begin{tabular}{|c|c|c|c|c|c|}
\hline $\begin{array}{l}\text { Author/ } \\
\text { Source }\end{array}$ & Research & $\begin{array}{l}\text { Market } \\
\text { under } \\
\text { research }\end{array}$ & $\begin{array}{l}\text { Time of } \\
\text { research }\end{array}$ & Conclusions & $\begin{array}{l}\text { Asses- } \\
\text { sment }\end{array}$ \\
\hline $\begin{array}{l}\text { Buszko, } \\
2013\end{array}$ & $\begin{array}{l}\text { RESPECT Index } \\
\text { compared to } \\
\text { traditional WIG } \\
\text { index and sector } \\
\text { sub-indices }\end{array}$ & Poland & 2009-2013 & $\begin{array}{l}\text { in a short-term period, } \\
\text { RESPECT Index generates } \\
\text { positive surplus return rates } \\
\text { over WIG and sector sub-in- } \\
\text { dices, however a long-term } \\
\text { valuation of social respon- } \\
\text { sibility remains unclear and } \\
\text { depends on a the character } \\
\text { of the company, as well as } \\
\text { its financial and economic } \\
\text { condition }\end{array}$ & $\begin{array}{l}\text { posi- } \\
\text { tive/ } \\
\text { neutral }\end{array}$ \\
\hline $\begin{array}{l}\text { Brzesz- } \\
\text { czyński } \\
\text { and McIn- } \\
\text { tosh, } 2014\end{array}$ & $\begin{array}{l}\text { FTSE4GOOD } \\
\text { Index compared to } \\
\text { FTSE100 index }\end{array}$ & UK & 2000-2010 & $\begin{array}{l}\text { differences in the return } \\
\text { between SRI index and } \\
\text { benchmark were not statisti- } \\
\text { cally substantial }\end{array}$ & neutral \\
\hline $\begin{array}{l}\text { Sudha, } \\
2015\end{array}$ & $\begin{array}{l}\text { ESG India Index } \\
\text { compared to } \\
\text { benchmark (indi- } \\
\text { ces): S\&P CNX } \\
\text { Nifty and S\&P } \\
\text { CNX 500 }\end{array}$ & India & 2005-2012 & $\begin{array}{l}\text { the effectiveness of ESG In- } \\
\text { dia index is higher in terms } \\
\text { of the annual return, howe- } \\
\text { ver the average daily return } \\
\text { of ESG India index does } \\
\text { not differ statistically from } \\
\text { average market thresholds }\end{array}$ & $\begin{array}{l}\text { posi- } \\
\text { tive/ } \\
\text { neutral }\end{array}$ \\
\hline
\end{tabular}

CSI index featured results higher than average a $101.8 \%$ growth, whereas other noted a lower dynamic of changes. In order of effectiveness: MSCI KLD 400 Social $(71 \%)$, DJSI North America (45\%), MSCI World ESG (32.9\%), FTSE4GOOD Global (26.6\%), STOXX Europe positive Sustainability (8.7\%), DJSI World $(7.3 \%)$. In the case of DJSI Europe index, a 1.7\% decrease was observed. In most cases a positive phenomenon relating to the behaviour of indices in the research period can be noticed.

Table 2. continued 


\begin{tabular}{|c|c|c|c|c|c|}
\hline $\begin{array}{l}\text { Author/ } \\
\text { Source }\end{array}$ & Research & $\begin{array}{l}\text { Market } \\
\text { under } \\
\text { research }\end{array}$ & $\begin{array}{l}\text { Time of } \\
\text { research }\end{array}$ & Conclusions & $\begin{array}{l}\text { Asses- } \\
\text { sment }\end{array}$ \\
\hline $\begin{array}{l}\text { Brzesz- } \\
\text { czyński, et } \\
\text { al., } 2016\end{array}$ & $\begin{array}{l}\text { FTSE4GOOD } \\
\text { GLOBAL } 100 \\
\text { compared to S\&P } \\
\text { Global 1200, } \\
\text { MSCI World Ener- } \\
\text { gy, FTSE ET50 } \\
\text { Index }\end{array}$ & $\begin{array}{l}\text { global } \\
\text { reach }\end{array}$ & $2005-2015$ & $\begin{array}{l}\text { no substantial differences } \\
\text { between the viability of SRI } \\
\text { and non-ecological indices } \\
\text { have been noticed }\end{array}$ & neutral \\
\hline $\begin{array}{l}\text { Laskow- } \\
\text { ska, } 2017\end{array}$ & $\begin{array}{l}\text { RESPECT Index } \\
\text { compared to } \\
\text { traditional Warsaw } \\
\text { Stock Exchange - } \\
\text { WIG }\end{array}$ & Poland & 2009-2016 & $\begin{array}{l}\text { the comparative analysis of } \\
\text { RESPECT Index and WIG } \\
\text { confirms that taking into } \\
\text { consideration ESG factors } \\
\text { can imply positive invest- } \\
\text { ment return rates, however, } \\
\text { due to too short time hori- } \\
\text { zon, possible disturbances } \\
\text { on the market or different } \\
\text { construction of indices, no } \\
\text { extraordinary profitability } \\
\text { of SRI investments can be } \\
\text { identified }\end{array}$ & neutral \\
\hline
\end{tabular}

While analysing the table it should be underlined above all that no certain conclusion as to the effectiveness of sustainability stock market indices can be made. Similarly to Table 1, what predominates is the neutral assessment proving the lack of substantial differences between the viability of CRS and traditional indices. Nevertheless, many researches point at the profitability of following the ecologically responsible benchmark. Apart from the cost-effectiveness, other advantages resulting from the existence of the index and taking part in it can be observed, namely: advertisement, public relations, and access to the capital of investors who take into consideration ESG factors when making business decisions.

\section{Verification of basic study hypotheses relating to SRI portfolios}

In the literature of the subject there are three hypotheses relating to the viability of eco-ethically responsible portfolio, at the background of traditional investing. They refer to the risk-adjusted return rate and read as follows (Janik, 2014):

a) doing good but not well - socially responsible investing pays the price in the form of worse investment results, when compared to traditional portfolios,

b) doing good while doing well - the viability of eco-ethical investments is higher than of conventional investments, 
GREEN CORPORATE SOCIAL RESPONSIBILITY

Anna Laskowska c) no effect - lack of disproportion between the return rates of ecologically responsible products and others.

A responsible investor wants to achieve return rates according to the two theses: "doing good while doing well" and "no effect". In a different situation, the investment activity including eco-ethical standards would negatively influence the portfolio of the market participant what, as a consequence, would decrease the number of those investors (Laskowska, 2016).

The studies of authors referring to the above mentioned hypotheses are presented in Tables 1 and 2. "Doing good but not well" requires a time-consuming and careful selection of CRS companies for the portfolio. Such process can be capital-intensive and it can even increase the variance measured risk. As a consequence, it can contribute to lower return rates from the portfolio. Such research was for example conducted by Gerczy.

The other hypothesis, "doing good while doing well", observed i.a. by Statman and Sikacz, can be confirmed for the following two reasons. First of all, taking into account eco-ethical norms constitutes a positive signal for the market participants, proving specific skills of the company's management, resulting in higher return rates. Secondly, the selection within the area of social responsibility can help in achieving higher viability in a time of crisis. This occurs because strict elimination serves a preventive role and decreases the risk of high costs incurred during recession (Bartkowiak and Janik, 2012), what was confirmed in the study by Nofsinger and Varma.

The phrase "no effect" predominates in earlier researches. It is the safest approach, equalising the profitability of SRI and traditional investments. Nonetheless, nowadays not only economic guidelines matter on the market but also one's own views and market trends.

On the basis of Tables 1 and 2 it can be tentatively claimed that eco-ethical investing can refer to "no effect" thesis or, to a lesser extent, "doing good while doing well". The confirmation of "doing good but not well" is the least probable. It should be stressed, however, that basing on the analysis of the subject literature, a clear conclusion concerning the profitability of social responsibility cannot be drawn. The reason for such variety of results can be: size of the sample, time horizon, market conditions and diversity of studied sectors.

\section{Conclusions}

The aim of the hereby thesis was to present the condition of the capital market with reference to ecological investing, through analysis of the results of previously conducted researches on the effectiveness of SRI investments.

The evidence presented in the article indicates, that financial markets sometimes reward SRI portfolios for their "ethical" level. Therefore the answer to the question which arose at the beginning, whether responsible investments 
can generate return rates higher than model investments, is affirmative. Green CSR on the financial market can earn profits to the investors, outperforming the benchmark. The problem is, however, that it does not occur often. The conclusion is made with a high degree of distrust but if "gains" are understood as the totality of benefits for the investor, the thesis becomes more certain. Thus it is worth reminding that CSR and SRI have a number of other advantages, such as improvement of the image, reduction of investment risk, diversification of the portfolio or being a part of the trend gaining more and more proponents. The aim is also to improve the natural environment.

The above statement is quite optimistic and a more realistic view on the issue is recommended. It should therefore be noted that studying Tables 1 and 2 can lead to a clear conclusion, that according to earlier subject literature and empirical studies in most cases there are no significant differences between ecoethical and traditional investments. That confirms the "no-effect" hypothesis and, in this connection, investors who meet their ethical values and invest in ecological financial instruments neither expose their portfolios to losses nor earn material profits. Yet again, due to a limited sample of studies analysed a more cautious approach to the conclusion is recommend. However, the activity of financial and economic institutions has an undisputed social and ecological dimension, therefore, when making investment decisions, it is advised to take environmental factors into consideration.

The issue is worth further exploration, as two kinds of profits can be achieved through the pro-ecological CSR segment of the financial market: economic and environmental. The number of analyses conducted proves that the subject is appealing and worth the attention. The research presented becomes a part of the discussion on the effectiveness of creating SRI portfolios, constituting a kind of summary of the reflections made so far. This, in turn, provides more meaningful and condensed arguments for further pondering over the subject of cost-effectiveness of ecological investing. Future scientific research can analyse the profitability of strictly ecological CSR financial instruments exclusively. Due to a constantly growing number and increasing importance of ecological stock market indices on the financial market, it is also necessary to put them under analysis.

To sum up, it can be stated that environmental protection in making investment decisions can be cost-efficient. Financial profits, as well as non-financial ones (mainly reputational) can be achieved by both the investor and the issuer. However, looking from a deeper, slightly idealistic perspective that through ecology, every member of society "earns". This expression should not be feared, as cleaner and less exploited environment - air, water, soil - is social benefit. 
GREEN CORPORATE SOCIAL RESPONSIBILITY

Anna Laskowska

\section{References}

Analizy.pl (2016), “Analiza: Warta EKO Trio UFK”, available at: http://www.analizy.pl/ fundusze/ubezpieczeniowe-fundusze-kapitalowe/profil-funduszu/UWAR144/WartaEKO-Trio-UFK.html (accessed 9 March 2017).

Bartkowiak, M., Janik, B. (2012), „Efektywność inwestycji w spółki z indeksu RESPECT oraz Funduszu Inwestycyjnego SKOK etyczny 2", Zeszyty Naukowe Uniwersytetu Ekonomicznego w Poznaniu, No. 242, pp. 7-18.

Bauer, R., Derwall, J., Otten, R. (2007), "The Ethical Mutual Fund Performance Debate: New Evidence from Canada”, Journal of Business Ethics, Vol. 70 No. 2, pp. 111-124. DOI: $10.1007 / \mathrm{s} 10551-006-9099-0$

Briston, R.J., Mallin, C.A., Saadouni, B. (1995), “The financial performance of ethical investment funds", Journal of Business Finance and Accounting, Vol. 22 No. 4, pp. 483-496. DOI: 10.1111/j.1468-5957.1995.tb00373.x

Brzeszczyński, J., Ghimire, B., Jamasb, T., McIntosh, G. (2016), "Socially responsible investment and market performance: the case of energy and resource firms", working paper 1605, Energy Policy Research Group, University of Cambridge, Cambridge, February.

Brzeszczyński, J., McIntosh, G. (2014), "Performance of Portfolios Composed of British SRI Stocks", Journal of Business Ethics, Vol. 120 No. 3, pp. 335-362. DOI: 10.1007/ s10551-012-1541-X

Buszko, M. (2013), "Efektywność inwestowania na rynku kapitałowym w spółki odpowiedzialne społecznie", in: Borys, G., Janusz, A. (Eds.), Rola instytucji i rynku finansowego w świetle celów oraz zasad zrównoważonego rozwoju, Research Papers of Wrocław University of Economics, Wrocław, pp. 20-30.

Christofi, A.C., Christofi, P., Sisaye, S. (2012), "Corporate sustainability: Historical development and reporting practices", Management Research Review, Vol. 35 No. 2 , pp. 157-173. DOI: 10.1108/01409171211195170

Corner, C.C., Luther, R.G., Matatko, J. (1992), "The Investment Performance of UK "Ethical” Unit Trusts", Accounting Auditing and Accountability Journal, Vol. 5 No. 4, pp. $57-70$.

Cortez, M.C., Leite, P. (2014), "Style and performance of international socially responsible funds in Europe", Research in International Business and Finance, Vol. 30 No. 1, pp. 248-267. DOI: 10.1016/j.ribaf.2013.09.007

Czakon, W. (2011), "Metodyka systematycznego przeglądu literatury", Przegląd Organizacji, No. 3, pp. 57-61.

Czerwonka, M. (2013), Inwestowanie społecznie odpowiedzialne, Difin, Warszawa.

Czerwonka, M., Wolska, M. (2013), "Społecznie odpowiedzialne inwestowanie - analiza rentowności funduszy SRI w Polsce”, Studia i Prace Kolegium Zarządzania i Finansów, No. 126, pp. 9-21.

Dziawgo, L. (2007), "Problem ochrony środowiska na rynku kapitałowym", Ekonomia i Środowisko, Vol. 31 No. 1, pp. 109-120.

Dziawgo, L. (2010), Zielony rynek finansowy. Ekologiczna ewolucja rynku finansowego, Polskie Wydawnictwo Ekonomiczne, Warszawa.

Geczy, C.C., Levin, D., Stambaugh, R.F. (2003), “Investing in Socially Responsible 
Mutual Funds", working paper, The Wharton School, University of Pennsylvania, Philadelphia, March.

Gray, R.H., Kreander, N., Power, D.M., Sinclair, C.D. (2005), "Evaluating the Performance of Ethical and Non-ethical Funds: A Matched Pair Analysis", Journal of Business Finance and Accounting, Vol. 32 No. 7-8, pp. 1465-1493. DOI: 10.1111/j.0306-6 86X.2005.00636.X

Janik, B. (2014), Inwestycje finansowe w koncepcji zrównoważonego rozwoju, Difin, Warszawa.

Koop, M. (2013), Socially Responsible Investment Fund Performance: The Impact of Social Screens and Intensity, School of Economics and Management, Tilburg.

Laskowska, A. (2016), "Ekologiczne fundusze inwestycyjne jako uczestnicy rynku kapitałowego", in: Kraiński, K. (Ed.), Rynek nieruchomości, pracy i finansowy kierunki rozwoju II, Fundacja HUTENA, Elbląg, pp. 167-180.

Laskowska, A. (2017), "RESPECT Index jako krok milowy w rozwoju społecznie odpowiedzialnego inwestowania w Polsce", in: Dziawgo, L., Walczak, D. (Eds.), Finanse - wyzwania wspótczesności. Perspektywa studentów, Wydawnictwo Naukowe UMK, Toruń, pp. 11-26.

Nofsinger, J., Varma, A. (2014), "Socially responsible funds and market crises", Journal of Banking and Finance, Vol. 48 No. 11, pp. 180-193.

Sikacz, H. (2016), "Porównanie wyników wybranych indeksów giełdowych przedsiębiorstw społecznie odpowiedzialnych na świecie", Acta Universitatis Lodziensis: Folia Oeconomica, Vol. 324 No. 4, pp. 213-225.

Statman, M. (2000), "Socially Responsible Mutual Funds", Financial Analysts Journal, Vol. 56 No. 3, pp. 30-39.

Sudha, S. (2015), "Risk-return and Volatility analysis of Sustainability Index in India, Environment", Development and Sustainability: A Multidisciplinary Approach to the Theory and Practice of Sustainable Development, Vol. 17 No. 6, pp. 1329-1342. 